\title{
God in het dagelijkse: De bijbelse God en de God van filosofen en kunstenaars
}

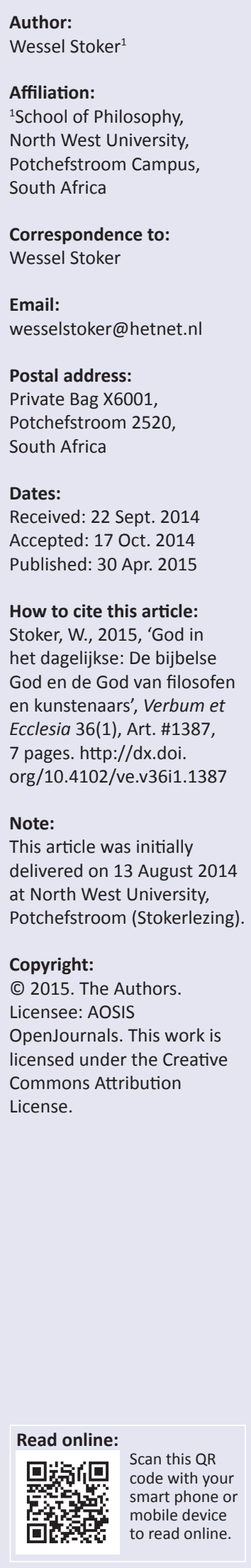

God in the everyday: The biblical God and the God of philosophers and artists. Life in secular Western society is lived and experienced within an immanent framework, with no reference to God. For many there is no longer any self-evident connection between God and ordinary life - ordinary life here broadly conceived as painted or narrated in art and literature. Since the time of the church fathers, the Christian tradition has conceived of God not only as personal but also, with reference to Exodus 3:14, as being or being-itself. Heidegger criticised this as onto-theology. Is it not better to speak about God without being (J-L Marion)? This problem is discussed from the approach of the philosophy of religion and it is argued that it is possible to speak about God in terms of being. This article further explores how Paul Tillich and Richard Kearney connect God with everyday life by speaking of God in terms of being. Tillich's ontology is a-historical and classical insofar as he uses the concepts of participation and analogia entis. Kearney proposes ontology as onto-eschatological, dynamic, historical, and hermeneutical. This article thus shows that the biblical God is viewed as the God of the philosophers in terms of being-itself (Tillich) and the God who may be (Kearney). The biblical God is also the God of the artists in whose works of art a trace of the religious ultimate is visible in the sacramental power of sensory reality or in secular epiphanies.

\section{Introductie Probleemstelling}

In de seculiere, westerse samenleving voltrekt zich het leven binnen een immanent kader (Taylor 2007). We zoeken voor onze problemen op het gebied van politiek, wetenschap en gezondheid gewoonlijk binnenwereldse oplossingen zonder een beroep op God. Voor velen is God niet meer vanzelfsprekend met het dagelijkse leven verbonden, want hoe is Hij te ervaren binnen het immanente kader van de maatschappij? Sommige filosofen verdedigen zelfs een religie zonder God of een religie zonder geloof, zoals Alain de Botton (2011) en Ger Groot (in de Boer \& Groot 2011). Ze willen wel sommige 'spullen' uit de boedel van de christelijke traditie als waardevol meenemen, zoals het ritueel en de onderlinge gemeenschap van mensen, maar alleen zonder geloof in God. Derrida zoekt in zijn ethiek naar een religie zonder religie, een messianisme zonder messias.

Anders dan deze filosofen die het vragen naar een religieuze God voorbij zijn, meen ik dat leven binnen een immanent kader geloven in God allerminst uitsluit. Meer dan in een traditionele maatschappij berust het geloven in God op een persoonlijke keuze (Stoker 2006). Ik wil in dit artikel een aanzet geven om God in het dagelijkse te zoeken. Het gaat mij niet om de vraag of God bestaat, maar hoe God in het dagelijkse werkzaam is. Dat dagelijkse vat ik ruim op: ook het dagelijkse zoals verbeeld of verhaald in kunst en literatuur. Ik doe dat vanuit de godsdienstfilosofie, waarbij ik gebruik maak van joods-christelijke teksten. Ik vermijd daarbij twee extreme posities. De ene positie plaatst God te gemakkelijk in het dagelijkse, waardoor het anders-zijn van God miskend wordt. God zou dan een zijnde en wel het hoogste zijnde zijn. Deze opvatting komt bij gelovigen voor, maar ook in de wijsbegeerte. Dat is de positie van de ontotheologie. In kritische reactie daarop benadrukt men terecht het verschil tussen God en wereld of mens, maar men doet dat soms zo radicaal dat God achter onze horizon verdwijnt en nauwelijks meer benoembaar is. Dat is de positie van radicale transcendentie, van alteriteit. Levinas en Marion pleiten voor een God 'anders dan zijn' of 'zonder zijn'. Als God met zijn verbonden wordt, dan loopt dat volgens hen uit op ontotheologie. Zij wijzen elke (analoge of eschatologische) zijnsovereenkomst tussen Gods werkelijkheid en de onze af. Is de prijs daarvoor niet dat God zo binnen de samenleving in het isolement raakt en de mogelijkheid om God in het dagelijkse te ervaren flinterdun wordt?

Vanaf de tijd van de kerkvaders heeft de christelijke traditie God niet alleen als persoonlijk opgevat, maar ook als zijn of zijnzelf. Op deze wijze kon men christendom en cultuur, God en het 
dagelijkse met elkaar verbinden, omdat zo Gods werkelijkheid op een of andere wijze met de dagelijkse werkelijkheid intervenieert.

In mijn zoeken naar God in het dagelijkse laat ik zien hoe voor twee denkers, Paul Tillich en Richard Kearney, God in het dagelijkse, ruim opgevat, kan oplichten. Tillich is de twintigste-eeuwse protestantse, filosofische theoloog bij wie het thema God en seculariteit centraal staat. De hedendaagse katholieke filosoof Kearney wil in discussie met de postmoderne filosofie de godsvraag op nieuwe wijze aan de orde stellen. God is voor beiden zo ruim als heel de werkelijkheid. Om dat te laten zien verbinden zij God en zijn, Gods werkelijkheid met die van mens en wereld, zij het op verschillende manier. Eerst wil ik echter wat dieper ingaan op die twee extreme posities: die van God zonder zijn bij Marion én de tegenpositie daarvan, God in de ontotheologie.

\section{God zonder zijn: Marion}

Het spreken over God als zijn is spreken over God als een idool, en dat is ontotheologie. Het alternatief is God als icoon te denken (Marion 1991, 2001). Idool onderstelt in het Grieks (eidolon) glans van het zichtbare. Het idool wordt bepaald door de menselijke blik. De intentie van het ik streeft naar het goddelijke om het goddelijke met zijn menselijke blik te zien. De gegevenheid van het idool is zo toegesneden op de menselijke maat. Het idool verzadigt de blik met zichtbaarheid. Het idool werkt als een spiegel, niet als een portret. De spiegel weerspiegelt het beeld van de blik. Het laat zo het goddelijke bepalen door de menselijke blik. Het idool kan een zichtbaar (afgods)beeld zijn, gestold in steen of hout, maar ook een begrip. Wanneer het filosofische denken in een begrip de naam van God wil uitdrukken, functioneert het als een idool en miskent het daarmee het onzichtbare van God. Het contrast is hier de icoon, letterlijk opgevat als 'eikon', beeld zoals Paulus spreekt over Christus als icoon, beeld van de onzichtbare God (Kol 1:15). Het idool is een representatie van het andere op grond van de menselijke blik of, in de termen van de fenomenologie van Husserl, op grond van de intentionaliteit van het ik en niet de representatie van een van mij onafhankelijke God. Spreekt men zo over God, dan gebeurt dat steeds binnen de beperkte horizon van de desbetreffende denker. Instemmend citeert Marion Feuerbach: 'het is de mens die het oorspronkelijke model is van zijn idool' (Marion 1991:16). Het conceptuele idool is zaak van ontotheologie.

De icoon is anders dan het idool niet het resultaat van de blik, maar roept het zien op door het zichtbare beetje bij beetje te verzadigen met het onzichtbare. Het onzichtbare verschijnt uiterlijk zo dat het het onzichtbare nooit reduceert tot het zichtbare. De icoon is bepaald door een oorsprong zonder origineel: een oneindige oorsprong die zichzelf geeft door de oneindige diepte heen van de icoon. De maat van de icoon is niet de wijdheid van de blik zoals bij het idool, maar dat zij zich overstijgt en daarmee afhankelijk is van het excessieve van het onzichtbare. Ook de icoon kan behalve beeld in hout, ook conceptueel zijn, zoals Descartes' spreken over God als idee van het oneindige dat het begrip als zodanig overstijgt en voorbij het zijn ligt.

Marion wil het spreken over God losmaken van de vraag van het zijn: 'het woord Zijn moet niet in een theologische verhandeling voorkomen' (Marion 1991:63). God is ondenkbaar en om dat aan te geven streept Marion de o in het woord God door met een (Andreas)kruis. Dit als teken van de verzoeking om de ondenkbare tot een idool te maken. De ondenkbare treedt alleen ons denken binnen door zichzelf door overmaat ondenkbaar voor te stellen en bekritiseert daarmee ons denken (Marion 1991:46, 2007). Marion laat op indrukwekkende wijze zien hoe God zonder zijn te denken is als gift. De gift hoeft niet eerst te zijn, maar het schenken van de gift is een zichzelf prijsgeven en dat alleen veroorzaakt haar te zijn (Marion 1991:3, 2002a).

Marions kritiek op God als idool overtuigt, maar zijn alternatief niet. Dat is een God zonder zijn, een godsopvatting die zoals in de mystieke theologie onbenoembaar is. Zo zijn de werkelijkheid van God en van mens volstrekt heterogeen en kan God moeilijk met het dagelijkse verbonden worden. De godsvraag dreigt zo in de cultuur in een isolement te komen. Marion zou tegenwerpen dat hij juist met behulp van zijn wijsgerige fenomenologie de mogelijkheid van een openbaring van God laat zien als een verzadigd fenomeen (Marion 2002a:199-221, 2002b). Plaatst hij hiermee God niet juist midden in de cultuur en geeft hij zo geen voorbeeld van God in het alledaagse? Marions beschrijving van een openbaring van God als een gesatureerd fenomeen overtuigt niet om de volgende reden. Gesatureerde fenomenen zijn fenomenen die zowel seculier kunnen zijn zoals de Franse Revolutie of het kijken naar een schilderij alsook religieus zoals een openbaring van God. Marion schermt zo'n openbaring van God echter scherp af van de seculiere gesatureerde fenomenen zodat de verbinding met het alledaagse moeilijk tot stand komt. Als model van het gesatureerde fenomeen 'openbaring' kiest hij de verblindende zonneklaarheid van Jezus' verheerlijking op de berg (Matt 17:1-13). Dat is juist een gebeuren waarop mensen zoals Petrus niet adequaat kunnen reageren. Dit verhaal is minder geschikt om als model van openbaring te gebruiken omdat de communicatie, de dialoog tussen God en mens die eigen is aan zo'n openbaringsgebeuren, juist ontbreekt. Zo'n dialoog is een onmisbaar onderdeel van een openbaringsgebeuren zoals de Schrift vertelt over een openbaring aan Mozes, Jesaja en Maria. Marion spreekt over openbaring op absolute wijze als Gods presentie die onze horizon verzadigt in een verblindende zonneklaarheid. Dit accent op het verblindende van het gebeuren maakt het bovendien niet mogelijk om te onderscheiden of zo'n openbaring van God komt of van iets anders (Kearney 2001:33). Marion (2002b) beschrijft het gesatureerde fenomeen 'openbaring' zoals de mystieke theologie spreekt over God als de onkenbare, over God als 'de afwezige', wiens naam niet te zeggen is, maar die ons enkel roept. Hij benadrukt radicale transcendentie zo sterk dat het lijkt alsof God alleen in een onverklaarbare flits in de mensenwereld 
verschijnt. Zo'n gebeuren kan zelfs traumatisch zijn voor de mens. Rembrandt bijvoorbeeld laat bij de aankondiging van de geboorte van Jezus de engel Gabriël Maria haast gewelddadig overschaduwen (De aankondiging aan Maria, ca. 1635). Het evangelieverhaal van de aankondiging benadrukt daarentegen juist de dialoog tussen Maria en de Engel over zijn boodschap. Zulk spreken over de absolute wijze van Gods presentie in een verblindende zonneklaarheid miskent dat de Evangeliën Gods werkelijkheid laten interveniëren in onze wereld, niet als een flits, maar als een gebeuren dat zich laat vertellen als een verhaal in tijd en ruimte. Zoiets lijkt mij onmogelijk vanuit Marions spreken over God als gift zonder zijn en daarmee zonder de categorieën van onze eindige werkelijkheid, ruimte, tijd, causaliteit en relatie. Openbaring opvatten als een gesatureerd fenomeen laat weinig ruimte voor een hermeneutiek ervan (Marion \& Kearney 2006: 319-320).

Het spreken over God als idool is inderdaad uiting van ontotheologie, van God als zijnde. Marion meent echter dat alle spreken over God in termen van zijn ontotheologie is. Als we zijn mystieke theologie van radicale transcendentie en zijn omschrijving van openbaring als gesatureerde fenomeen afwijzen, ontstaat er een patsituatie, tenzij niet alle spreken over God als zijn of zijnzelf uiting is van ontotheologie.

\section{Ontotheologie? Een gap in meaning}

De kritiek op de ontotheologie van Marion en andere postmoderne godsdienstfilosofen gaat op Heidegger terug. Heidegger bekritiseerde de ontotheologie als een foute wijze van spreken over God. Hij ziet dat met name bij Aristoteles, Leibniz en vooral Hegel. Ontotheologisch spreken over God is God als mysterie ontkennen en zo over hem spreken alsof de hele werkelijkheid voor de mens begrijpelijk is. Zulk spreken vind je bij Aristoteles als hij God de top van de zijnden, het hoogste zijnde noemt; Leibniz doet het door de oorzakelijkheid in de wereld via het principe van de voldoende grond terug te voeren tot de ultieme oorzaak, en Hegel door heel de werkelijkheid te begrijpen vanuit de godsgedachte. Ontotheologie houdt in berekenend-representationeel over God spreken (Heidegger 1957; Westphal 2001). Marion gaf dat scherp aan in zijn analyse van het idool, God als een door de mens zelf gemaakt beeld. Maar wat is het alternatief als de weg van radicale transcendentie van Marion geen optie is? In ieder geval gaat het om het inzicht dat God de mens oneindig transcendeert, om het inzicht dat 'God van God komt'. Dat sluit een spreken over God niet uit (Muis 2011). Heidegger handhaaft de vraag van het zijn, maar onderscheidt deze van de vraag naar God, die voor hem niet meer de bijbelse God is. Levinas acht de zijnsleer uiting van een totalitair, gewelddadig denken en spreekt over God, generzijds van het zijn, in ethische zin via het gelaat van de ontrechte. Zo wordt de ontologie vervangen door de ethiek. Het spreken over God in ethische zin is weliswaar onmisbaar, onopgeefbaar, en zet de traditie van de joodse profeten voort, maar God is behalve wetgever ook schepper en verlosser. God is wijder dan de ethiek. Laten we eens bekijken hoe de zijnsvraag in het bijbels spreken over God aan de orde is.
In het bijbelse spreken over God wordt over Hem ook gesproken in termen van zijn. Dat gebeurt bij Mozes' ontmoeting met God in de brandende braamstruik. Mozes krijgt de opdracht om de Israëlieten uit Egypte te leiden. Op de vraag wat de naam is van de God die hem gestuurd heeft, antwoordde God: 'Ik ben die er zijn zal ...; “IK ZAL ER ZIJN heeft mij naar u toe gestuurd"' (Ex 3:14). Het spreken in zijnstermen over God (en Christus) wordt herhaald in het Nieuwe Testament (Joh 8:58, Rom 4:17, 1 Kor 1:28, Op 1:4, 8, 4:8, 11:17). De Septuagint en de Vulgaat hebben het Hebreeuwse 'ehyeh' 'aser 'ehyeh' vertaald met respectievelijk ego eimi ho on en sum qui sum. Zo komt het spreken over God in zijnstermen in de filosofie en in de theologie. Als men beweert dat alle spreken over God in zijnstermen ontotheologie is, vergeet men dat het zijnsbegrip een polyseem begrip is; het heeft niet één betekenis maar meerdere betekenissen die niet volledig van elkaar verschillen. Met Ricoeur kan men inzake de term 'zijn' spreken over een gap in meaning. Dat geeft de mogelijkheid het begrip verschillend te stempelen (Ricoeur 1998). Dat is gebeurd vanaf de joodse filosoof Philo van Alexandrië (25 v.Chr.-50 na Chr.), toen men op grond van Exodus 3 ging spreken over de bijbelse God in zijnstermen. Verschillend stempelen houdt ook in dat dit ontotheologisch kan gebeuren zoals bijvoorbeeld in de late scholastiek, bij Leibniz en Hegel. Maar met de vertaling van het Hebreeuwse hyh/'ehyeh kon ook een meer overtuigende interpretatie van zijn meekomen van Thomas van Aquino in zijn spreken over God.

Ik laat zien hoe in onze tijd Paul Tillich en Richard Kearney het zijnsbegrip dopen in hun ontologisch spreken over God met vermijding van ontotheologie. Zijn is voor hen de basis om in de seculiere tijd God met het dagelijkse te verbinden. We zullen zien dat ze elk God en zijn verschillend met elkaar verbinden. Dat is gegeven met het polyseme karakter van zijn. Tillichs ontologie is meer klassiek, terwijl Kearney het begrip zijn stempelt in de context van het postmodernisme.

\section{God in het dagelijkse God als zijnzelf én als persoonlijk: Tillich}

Tillich spreekt behalve over een persoonlijke God, ook over God als het zijnzelf. Wat houdt het in dat God het zijnzelf is én de macht van zijn? In het woord 'werkelijkheid' zit het woord 'werken'. Wat werkt, moet macht hebben. Het niet-werkelijke is het onmachtige. 'Het onvoorwaardelijkwerkelijke ... overstijgt elke macht van de werkelijkheid. Het is het overstijgen, de transcendentie zelf' (Tillich 1927, 1961:4, 84). Zo duidt het begrip zijn en het zijnzelf op de macht die in alles inherent is: de macht om het niet-zijn te weerstaan. God is de macht van zijn in alles en boven alles, de oneindige macht van zijn (Tillich 1968a:261).

Tillich laat zien dat mensen binnen en buiten de christelijke geloofsgemeenschap in het dagelijkse betrokken zijn op de ultieme werkelijkheid. Dit impliceert dat ieder mens moed om te zijn nodig heeft en dat we die kracht alleen kunnen ontlenen aan de macht van zijn die alle tegenkrachten, het 
niet-zijn, heeft overwonnen. Daartoe is geen eindig zijnde in staat, bedreigd als het wordt door het niet-zijn. Die macht van zijn kan alleen het zijnzelf zijn dat in zichzelf het nietzijn heeft overwonnen. Tillichs spreken over God als het zijnzelf is bijbels gestempeld. Het gaat hem om de God van gerechtigheid en liefde. We danken onze moed om te bestaanen dat geldt elk mens - aan onze participatie in 'macht van zijn die het wint van het niet-zijn' (Tillich 1980:175).

Het ultieme is in het dagelijkse niet alleen aanwezig als bron van onze moed om te zijn, maar ook als de dieptedimensie van de werkelijkheid. Juist daarop stuiten wij in het kijken naar kunst, omdat kunst op een of andere wijze de werkelijkheid in haar religieuze diepte laat zien. En daarbij gaat het niet alleen om religieuze voorstellingen, maar ook om alledaagse dingen zoals het Dansend paar van Jan Steen (1663), waarin iets zichtbaar is van de macht van zijn. Vooral kunst in expressieve stijl laat iets oplichten van de religieuze diepte in de werkelijkheid zoals een stilleven van Cézanne of de zaaier van Van Gogh (Tillich 1987).

Men kan tegenwerpen dat het zijnzelf onpersoonlijk is en daarom moeilijk te verenigen is met een persoonlijke God. Dat is bij Tillich niet het geval. Hij vult de gap in meaning in het zijnsbegrip zo in dat zijn en persoon verschillende aspecten van God zijn die niet met elkaar tegenstrijdig zijn (Tillich 1955, 1961:5, 138-184; Stoker 1995). De bijbelse God gaat als een persoonlijke God een verbond aan met mensen en geeft zijn Wet en toont zich in Jezus als het nieuwe zijn. Spreken over God als het zijnzelf drukt uit dat het zijnzelf tegenwoordig is in alles en alles in het zijn-zelf participeert. Dit dubbele spreken over God als het zijnzelf en als persoonlijk wijst op een gelaagd godsbegrip en laat zien dat mensen verschillende relaties met God kunnen hebben, persoonlijke en niet-persoonlijke.

Tillich spreekt over God als zijnzelf, om het met Marion te zeggen, niet als idool maar als icoon. Hij vermijdt ontotheologie. Als God een zijnde zou zijn, dan is hij onderworpen aan de categorieën van de eindigheid. Hij corrigeert daarom het theïsme voor zover het spreekt over God als een zijnde naast andere. Zo zou God tot deel van de werkelijkheid worden en daarmee onderworpen zijn aan haar ontologische structuur. De verhouding van God en mens zou dan volgens Tillich die zijn van God als subject tegenover de mens als object. Zo'n God is een tiran en is volgens Nietzsche dood (Tillich 1980:176-179, 1968a:301). God als zijnzelf is daarentegen de oneindige macht van zijn in alles en boven alles en transcendeert oneindig elk eindig zijn (Tillich 1968a:261, 1968b:6). Er is geen gradatie tussen eindig en oneindig maar een breuk of 'sprong'. In dit opzicht benadrukt Tillich met de postmoderne filosofie het radicale verschil, de alteriteit van God en wereld, maar tegelijk wijst hij ook op de immanentie van het zijnzelf in de wereld (Tillich 1968a:263). Tillich verdedigt wat immanente transcendentie is te noemen. Om ontotheologie te vermijden kiest hij juist de niet-letterlijke taal van het symbool om over God te spreken. Voor ons spreken over God gebruiken we materiaal ontleend aan de dagelijkse ervaring, met tegelijk een ja en een nee. We zeggen iets over Hem en ontkennen het tegelijk omdat God alles transcendeert wat over Hem kan worden gezegd (Tillich 1961:8, 81). Het spreken over God beperkt Tillich dus niet zoals Marion tot de negatieve theologie, maar vult die aan met de positieve theologie. Alleen de uitspraak God is het zijn-zelf is niet-symbolisch en verwijst niet buiten zichzelf. Het betekent direct wat het zegt (Tillich 1968a:264).

Tillichs ontologie is klassiek voorzover hij gebruik maakt van de participatie-opvatting en van de analogia entis in zijn symboolopvatting. Zijn ontologie is statisch en a-historisch. Hij leest de Schrift symbolisch met het oog op de relatie van het eindige met het oneindige. Zo komt het evangelie als verhaal niet tot zijn recht. Het verhaal vereist tijd, heeft een begin en einde, een plot. Daar kan Tillich geen recht aan doen omdat hij over God alleen in symbolen en niet in verhalen spreekt (Stoker 1998). Aan deze bezwaren komt Kearney tegemoet door de ontologie dynamisch, historisch en hermeneutisch op te vatten. Hij vult de gap in meaning als volgt anders in.

\section{'God die kan zijn' en het sacramentele van de werkelijkheid: Kearney}

Kearney wijst Marions spreken over God als 'anders dan zijn' of 'zonder zijn' af. Zo'n God van de negatieve theologie biedt geen mogelijkheid om God ter sprake te brengen in de taal van symbool of verhaal (Kearney 2001:7). Zoals Tillich zoekt hij God in het alledaagse (Kearney 2006:3, 10). Anders dan Tillich benadrukt hij dat dit zich alleen laat vertellen als een open verhaal, open voor het komen van God. Hij geeft een radicalere herinterpretatie van God en zijn en spreekt 'onto-eschatologisch' over God (Kearney 2001:37, 2006:7, 14). Zijn these is: 'Noch is God, noch is hij niet, maar hij kan zijn' (Kearney 2001:1). God is niet een esse, noch een nihil, maar possest zoals Cusanus zegt: absolute mogelijkheid die alles insluit wat werkelijk is (Kearney 2001:103-105). De gap in meaning van het zijnsbegrip in Exodus 3 vult Kearney in door in zijn zijnsleer de mogelijkheid niet als gerealiseerde werkelijkheid te beschouwen maar de mogelijkheid boven de feitelijke werkelijkheid te plaatsen. God is de mogelijkheid van het onmogelijke; God maakt onze wereld mogelijk ('possibilizes') vanuit de toekomst. (De term mogelijkheid vat Kearney niet op als een categorie van de modale logica, maar als een eschatologich posse vanuit een postmetafysisch perspectief.)

Op de vraag wat hij verstaat onder de 'mogelijk makende God' ('possibilizing God') antwoordt Kearney dat God een voortdurend aanbod is van de mogelijkheid van het Rijk van God. Dat houdt enerzijds de eschatologische belofte in van het Rijk van God aan het einde van de geschiedenis en anderzijds het 'hier en nu' ervan in het mosterdzaad, in het kleine, alledaagse, kwetsbare' (Marion \& Kearney 2006:372). Om dat hier en nu van het Rijk Gods gaat het Kearney, om het herstel van het eschaton in het hart van de dingen dat niets minder is dan de herontdekking van 
het kunnen (posse) in het zijn (esse). Het kunnen stroomt van God naar de mens en weer terug zoals een rivier in een eindeloze stroom (Kearney 2006:15). Het proces van vernieuwing, van transfiguratie is een samenspel van God en mens. Gods Rijk komt er niet zonder dat de mens eraan meewerkt. 'We kunnen God vernietigen, daarom spreek ik van God die kan zijn, dat is een interpretatie van Exodus 3:14: 'Ik ben de God die zal zijn, die kan zijn'. Zou God in de brandende braamstruik aan Mozes verklaren dat Hij is die Hij simpel is, dan is er sprake van een reeds vervuld zijn en zou God zijn rol als belofte opgeven (Marion \& Kearney 2006:367, 371).

We moeten Kearney's 'God who may be' niet opvatten als een voorwaardelijke God. Gods toekomst is weliswaar afhankelijk van onze handelingen in de geschiedenis, maar Gods oneindige liefde is dat niet volgens hem. 'Als een gift is God onvoorwaardelijk gevend'. Men kan alleen spreken over de God van de belofte als Hij die de belofte geeft is, dus aan Hem komt zijn (esse) toe. 'In de circulaire woorden Ik ben die ik kan zijn, transfigureert en overstijgt God zijn. Z'n esse openbaart zichzelf, verrassend en dramatisch als posse (kunnen)' (Kearney 2001:37). Zulk spreken over God in termen van zijn als kunnen, hangt dus nauw samen met zijn accent op het samenspel van God en de verantwoordelijke mens in de verwerkelijking van het beloofde rijk van gerechtigheid en liefde. Gods woord tot Mozes legt Kearney uit als een belofte: 'Ik ben die kan zijn als jij doorgaat mijn woord te houden en strijdt voor de komst van gerechtigheid' (Kearney 2001:37-38; oorspronkelijke tekst cursief gedrukt).

Zoals bij Tillich gaat het ook bij Kearney in zijn zoeken naar God in het alledaagse om een verbinding tussen de God van Abram, Isaak en Jakob en de God van filosofen en kunstenaars. Daarvoor wijst hij op Merleau-Ponty's fenomenologische ontologie en op romans van Joyce, Proust en Woolf. Het zijn voorbeelden van een sacramentele opvatting van de werkelijkheid. Het woord sacrament is hier breed op te vatten als zintuiglijke waarneming gevuld met betekenis.

Merleau-Ponty had in zijn Fenomenologie van de waarneming geschreven dat wat het sacrament van de eucharistie voor de gelovige is, het zintuiglijke is voor de ervaren waarnemer. Hij wijst daarmee op de eucharistische kracht van het zintuiglijke. Merleau-Ponty (1997) zegt dat zo:

Zoals het sacrament niet alleen onder de gedaante van het zintuiglijk waarneembare een werking van de goddelijke genade symboliseert, maar bovendien de werkelijke aanwezigheid van God is, en zoals het sacrament deze aanwezigheid een stuk van de ruimte laat innemen en deze aan degenen die het gewijde brood eten meedeelt voor zover zij er innerlijk op zijn voorbereid, zo heeft het zintuiglijk waarneembare niet alleen een motorische en vitale betekenis, maar het is ook niets anders dan een zekere wijze van in de wereld zijn die zich vanuit een punt in de ruimte aan ons aanbiedt en die ons lichaam overneemt en op zich neemt voor zover het daartoe in staat is: de gewaarwording is letterlijk een communie. (p. 260; vgl. Kearney 2010)
Merleau-Ponty laat hier in zijn waarnemingsleer een andere houding tegenover de dingen zien dan we in de verwetenschappelijktesamenleving gewend zijn. Hijvervangt Descartes' en Kants opvatting van een subject tegenover een object door een meevoelende waarnemingshouding die het uitwendige niet als objecten tegenover zich stelt, 'maar veeleer met ze meevoelt, ze tot de zijne maakt ...' (MerleauPonty 1997:262). Zo is elke zintuiglijke ontmoeting met de vreemdheid van de wereld een 'geboortepact' waar, door het meevoelen, het menselijk zelf en de vreemde wereld aan elkaar geboorte geven. De sacramentele gewaarwording is zo een omkeerbaar verband tussen mijzelf en de dingen, waarin het zintuiglijke door mij geboorte geeft aan zichzelf (Kearney 2011:89).

Ookbijauteurs als Proust, Joyce en Virginia Woolf zietKearney voorbeelden van sacrale ervaringen in het alledaagse: 'de eucharistie in een stukje madeleine-koek. Het Koninkrijk in een beker koud water. De San Marco in een ronde straatkei. God in een kreet op straat' (Kearney 2006:3, 2011:102, 110). Kearney ziet transcendentie oplichten in de romans van deze auteurs en wel ingeschreven in alledaagse immanentie. Het zijn seculiere voorbeelden voor Kearney van immanente transcendentie. 'Het mysterie wordt bewaard, zelfs gevierd ... als een mystieke affirmatie van het vleselijke bestaan: Woord tot vlees geworden in het dagelijkse universum' (Kearney 2011:102). Het zijn epifaniën waarin een alledaags seculier moment verandert in een heilige tijd (Kearney 2011:105). Merleau-Ponty wees op het sacramentele in de waarneming van de ruimte. In deze romans gaat het om het sacramentele in de tijd: door een herinnering gebeurtenissen laten herleven doordat men de verbinding laat zien tussen verschillende objecten, de verborgen verbindingen tussen het ene ding en het andere (Kearney 2011:113).

Kearney wijst fascinerend op God in het dagelijkse in de ontologie van Merleau-Ponty en bij genoemde romanschrijvers, maar overtuigt het ook? Men kan met O'Leary tegenwerpen dat Merleau-Ponty (en genoemde romanschrijvers) zelf uit zijn (hun) sacramentele visie op de werkelijkheid geen theologische gevolgen hebben getrokken. Merleau-Ponty spreekt over het zijn uitsluitend in zijn worsteling om mens en natuur wederzijds nauw op elkaar te betrekken, dus ontologisch en niet meta-fysisch. In zijn visie op het christendom is hij verwant aan de theoloog Thomas Altizer. Het absolute is niet buiten de wereld maar door incarnatie en het kruis van Christus blijvend in de wereld, waarmee een aan de wereld transcendente God is afgewezen.

De betekenis van Pinksteren is dat zowel de religie van de Vader als van de Zoon zich vervullen in de religie van de Geest, dat God niet langer in de hemel is maar in de menselijke samenleving en in de gemeenschap waar mensen ook samenkomen in zijn Naam (Merleau-Ponty in Simpson 2014:91).

Zegt Kearney niet teveel als hij beweert dat Merleau-Ponty God weer verbindt met deze wereld, een transcendentie in 
de immanentie? Merleau-Ponty wijst zoals gezegd alleen op de ontologische diepte van de waargenomen wereld zonder dit zelf te verbinden met God. Hij en de genoemde schrijvers gebruiken weliswaar christelijk-religieuze termen in hun werk. Proust bijvoorbeeld spreekt in sacramentele taal over transsubstantiatie, opstanding en openbaring (Kearney 2011:110). Dat wil nog niet zeggen, aldus O'Leary, dat hier sprake is van God in het dagelijkse. Het is eerder een openbreken naar transcendentie binnen de seculiere, eindige wereld (O’Leary 2010).

Ik deel O'Leary's kritiek niet. Kearney zou kunnen antwoorden dat deze 'terugkeer van het sacramentele' noch theistisch, noch atheistisch is; het zijn 'nieuwe mogelijkheden van incarnatie' (Kearney 2011:104). MerleauPonty wijst onmiskenbaar op de eucharistische kracht van het zintuiglijke. Juist kunst kan een eucharistische transformatie van het dagelijkse bewerken. Ik zou deze hier door Kearney aangewezen sacramentaliteit in kunst geen teken, maar een spoor van God willen noemen. De term teken impliceert rechtstreeks de verwijzing naar God. De term spoor doet meer recht aan de wirwar van verwijzingen in het dagelijkse en laat de interpretatie open voor een seculiere of een religieuze uitleg. Zelf stel ik voor om Merleau-Ponty en de genoemde schrijvers vanuit Kearney's christelijk gezichtspunt te lezen als voorbeeld van immanente transcendentie, als een spoor van God in het dagelijkse. En dan heeft het begrip spoor de connotatie van sacramenteel, van werkelijkheid gevuld met goddelijke betekenis. Ik beschouw zijn gewaagde visie als in een weddenschap beweren dat deze religieuze uitleg de voorkeur verdient boven de seculiere van Merleau-Ponty en de genoemde romanschrijvers. De juistheid ervan is alleen eschatologisch te verifiëren. Zo'n verificatie is kenmerkend voor de christelijke godsdienst die immers eschatologisch van karakter is. Zo'n verificatie geldt trouwens ook van Tillichs spreken over de moed om te zijn in verwijzing naar het zijnzelf. Met zo'n stellingname van Tillich en Kearney ben je voorbij aan de tegenstelling theïsme en atheïsme.

\section{Conclusie: De bijbelse God en de God van filosofen en kunstenaars}

God zoeken in het dagelijkse in een seculiere tijd? Mogelijk zijn er andere manieren om dat (godsdienst)wijsgerig te doen als ik heb gedaan. Ik heb de weg gekozen van herijkingen van de zijnsleer zoals voorgesteld door Tillich en Kearney. De een deed dat klassiek via participatie en de analogie van het zijn, de ander in een postmoderne context met de noties van historiciteit, praxis en eschatologie. Legt men een te sterke nadruk op Gods alteriteit, dan dreigt men vast te lopen in de negatieve theologie die God onnoembaar acht. Wil men God in het dagelijkse ter sprake brengen, dan dient men transcendentie te verbinden met immanentie, dat is de positie van immanente transcendentie. God in het alledaagse zoeken houdt in dat men het heilige niet tegenover het profane plaatst, maar in het profane. John Henry Newman (1801-1890) schreef treffend (in Borgman 2014): voor christenen is een poëtische visie op de dingen een plicht ... wij zijn eraan gehouden alle dingen te kleuren met de tinten van het geloof, om een goddelijke betekenis en een bovennatuurlijke gerichtheid te zien in elke gebeurtenis. (p. 61)

Is de bijbelse God de God van filosofen? De aanduiding 'God van filosofen' is te wijds om daar in het algemeen een genuanceerd antwoord op te geven. Het hangt ervan af welke filosoof of filosofie je op het oog hebt. Mij beperkend tot wat in het voorafgaande is gezegd, beantwoord ik de vraag bevestigend. Ja, de bijbelse God is de God van filosofen opgevat als het zijnzelf of als de God die kan zijn.

Is de bijbelse God de God van kunstenaars? Hier geldt een soortgelijk antwoord. De aanduiding 'God van kunstenaars' is te wijds om daar in het algemeen een genuanceerd antwoord op te geven. Wat het voorafgaande betreft: ja, de bijbelse God is de God van kunstenaars in wier werk een spoor van het religieus ultieme oplicht in de sacramentele kracht van het zintuiglijke of in seculiere epifaniën.

God zoeken in het dagelijkse, daarvoor is een met verbeelding naar mens en wereld kijken onmisbaar. Verbeelding is voor religie en kunst het sleutelwoord. In de christelijke godsdienst gaat het om het komende en gekomen Rijk van God. Jezus spreekt daarover met poëtische verbeelding in de taal van de parabels als een mosterdzaad, een parel, een schat in de akker. Kunst, theater, dans, muziek, film en literatuur bieden soms ook een opening van zo'n andere mogelijke wereld die de grenzen van onze feitelijke wereld overschrijdt.

\section{Tegenstrijdige belangen}

De auteur verklaart geen financiële of persoonlijke belangen te hebben die hem ongepast kunnen hebben beïnvloed bij het schrijven van dit artikel.

\section{Literatuurverwijzingen}

Borgman, E., 2014, 'Openbaring als poëzie: Leven in een land van beloften', Tijdschrift voor Theologie 54(1), 56-78.

Caputo, J. \& Scanlon, M. (eds.), 2007, Transcendence and beyond: A postmodern inquiry, Indiana University Press, Bloomington, IN.

De Boer, T. \& Groot, G., 2011, Religie zonder God: Een dialoog, Uitgeverij Sjibbolet, Zoetermeer.

De Botton, A., 2011, Religie voor atheïsten: Een heidense gebruikersgids, Uitgeverij Atlas, Amsterdam.

Heidegger, M., 1957, Identität und Differenz, Günther Neske, Pfullingen.

Hummel, G. (ed.), 1995, The theological paradox, De Gruyter, Berlin.

Hummel, G. (ed.), 1998, Truth and history: A dialogue with Paul Tillich, De Gruyter, Berlin.

Kearney, R., 2001, The God who may be: A hermeneutics of religion, Indiana University Press, Bloomington, IN.

Kearney, R., 2006, 'Epiphanies of the everyday: Toward a micro-eschatology', in J. Manoussakis (ed.), 2006, After God: Richard Kearney and the religious turn in continental philosophy, pp. 3-20, Fordham University Press, Bronx, NY.

Kearney, R., 2010, 'Merleau-Ponty and the sacramentality of the flesh', in K. Semonovitch \& N. DeRoo (eds.), 2010, Merleau-Ponty at the limits of art, religion, and perception, pp. 147-166, A\&C Black, London.

Kearney, R., 2011, Anatheism: Returning to God after God, Columbia University Press, New York.

La Cocque, A. \& Ricoeur, P., 1998, Thinking biblically: Exegetical and hermeneutical studies, University of Chicago Press, Chicago.

Manoussakis, J., 2006, After God: Richard Kearney and the religious turn in continental philosophy, Fordham University Press, Bronx, NY. http://dx.doi.org/10.5422/ fso/9780823225316.001.0001 
Marion, J-L., 1991, God without being: Hors-texte, University of Chicago Press, Chicago.

Marion, J-L., 2001, The Idol and distance: Five studies, Fordham University Press, Bronx, NY.

Marion, J-L., 2002a, Being given: Toward a phenomenology of givenness, Stanford University Press, Palo Alto, CA.

Marion, J-L., 2002b, In excess: Studies of saturated phenomena, Fordham University Press, Bronx, NY.

Marion, J-L., 2007, 'The impossible for man - God', in J. Caputo \& M. Scanlon (eds.), Transcendence and beyond: A postmodern inquiry, pp. 17-43, Indiana University Press, Bloomington, IN.

Marion, J-L. \& Kearney, R., 2006, 'Hermeneutics of Revelation', in J. Manoussakis, After God: Richard Kearney and the religious turn in continental philosophy, pp. 318-339, Fordham University Press, Bronx, NY. http://dx.doi.org/10.5422/ pp. 318-339, Fordham Unive
fso/9780823225316.003.0022

Merleau-Ponty, M., 1945, Phénoménologie de la perception, Librairie Gallimard, Paris.

Merleau-Ponty, M., 1997, Fenomenologie van de waarneming, Uitgeverij Boom, Meppel.

Muis, J., 2011, 'Can Christian talk about God be literal?', Modern Theology 27(4), 582607. http://dx.doi.org/10.1111/j.1468-0025.2011.01704.x

O'Leary, J., 2010, 'Merleau-Ponty and modernist sacrificial poetics: A response to Richard Kearney', in K. Semonovitch \& N. DeRoo (eds.), Merleau-Ponty at the limits of art, religion, and perception, pp. 167-184, A\&C Black, London.

Ricoeur, P., 1998, 'The revelation of Revelations', in A. La Cocque \& P. Ricoeur, Thinking biblically: Exegetical and hermeneutical studies, pp. 307-330, University of Chicago Press, Chicago.
Semonovitch, K. \& DeRoo, N. (eds.), 2010, Merleau-Ponty at the limits of art, religion, and perception, A\&C Black, London.

Simpson, B., 2014, Merleau-Ponty and theology, Bloomsbury, New York.

Stoker, W., 1995, 'The paradox of complementarity in Tillich's doctrine of God', in G. Hummel (ed.), The theological paradox, pp. 104-121, De Gruyter, Berlin.

Stoker, W., 1998, 'Faith, truth and history', in G. Hummel (ed.), Truth and history: A dialogue with Paul Tillich, pp. 103-120, De Gruyter, Berlin.

Stoker, W., 2006, Is faith rational? A hermeneutical-phenomenological accounting for faith. Peeters, Leuven.

Taylor, C., 2007, A secular age, Harvard University Press, Cambridge, MA.

Tillich, P. (Dillenberger, J. \& Dillenberger J., eds.), 1987, On art and architecture, Crossroad Publishing, New York.

Tillich, P., 1927, Gläubiger Realismus: zum Problem des religiösen Sozialismus, n.p.

Tillich, P., 1955, Biblische religion und die Frage nach dem Sein, Evangelisches Verlagswerk, Stuttgart.

Tillich, P., 1961, Gesammelte Werke (GW), Evangelisches Verlagswerk, Stuttgart.

Tillich, P., 1968a, Systematic Theology: Volume 1, Nisbet, London.

Tillich, P., 1968b, Systematic Theology: Volume 2, Nisbet, London.

Tillich, P., 1980, The courage to be, Collins, Glasgow.

Westphal, M., 2001, Overcoming onto-theology: Toward a postmodern Christian faith, Fordham University Press, Bronx, NY. http://dx.doi.org/10.5422/fso/97808 23221301.001.0001 